\title{
GIS APPLICATION ON RISK HAZARDS ASSESSMENT, CASE STUDY (THE NILE VALLEY, EGYPT)
}

\author{
Amin, A. M. ${ }^{1}$ and Helal Y. Esam ${ }^{2}$
}

\begin{abstract}
GIS has gained considerable importance in engineering applications particularly in the fields of hydrology and hydraulics. The present paper assessed the risk of the Aswan High Dam, AHD breaching, numerically. Flood model was chosen and was selected to be implemented. The outflow hydrograph due to fail of AHD are considered as the output of Abdelhaleem F. study (2011). Then, SOBEK 1D2D model was implemented in order to simulate the flood wave propagation and inundation area in the Nile Valley. Geographical Information Systems, GIS tools was used to manage the input and output results, and also was used to produce a precise Digital Elevation Model, DEM to the Nile Valley, Egypt, and implemented in order to determine the banks violation sites together with the inundation of surrounding areas. So the size of expected damage of national main structures, (Railways, roads, airports, etc) within the extension of the study area was identified using GIS spatial database. The final obtained raster maps were handled and analyzed mutually with up-to-date maps of GIS thus more applicable results. The time of flood wave propagations along the Nile was calculated in order to define the time of response for emergency measures to be operated. The results could put forward to a flood management plan and could suggest evacuation plans.
\end{abstract}

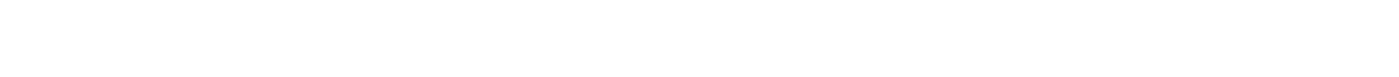

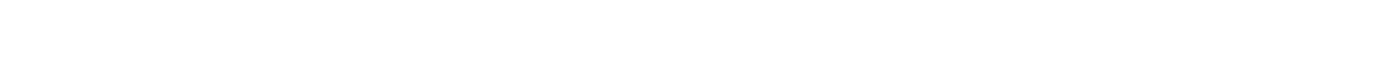

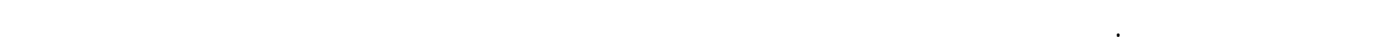

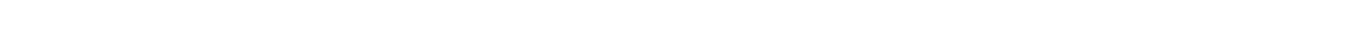

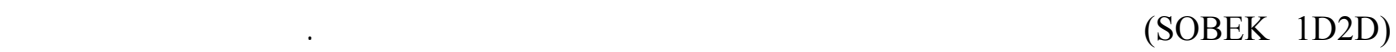

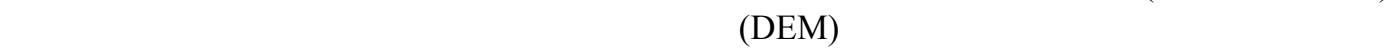

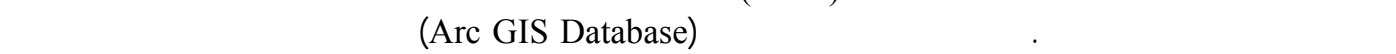

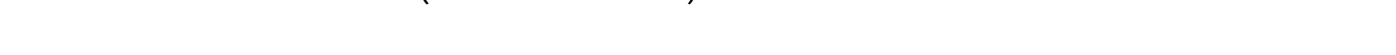

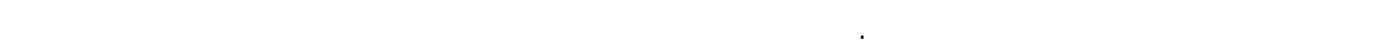

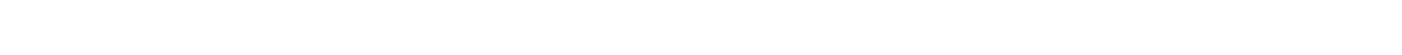

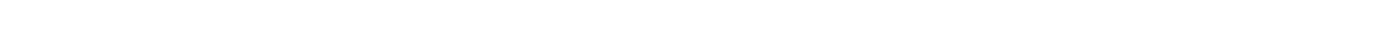

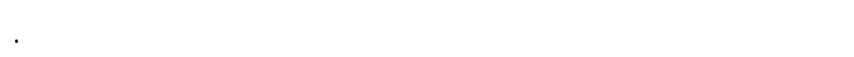

Keywords: Flood Model, GIS, DEM, Inundation Hazards, The Nile Valley.

\footnotetext{
${ }^{1}$ Researcher, Hydraulics Research Institute, National Water Research Centre, Egypt a.amin@hri-egypt.org

${ }^{2}$ Ass. Prof., Civil Engineering Department, Faculty of Engineering, Minufiya University, Egypt esameman@yahoo.com
} 


\section{INTRODUCTION}

Dams play vital roles in the economy of countries as they provide essential benefits like irrigation, hydropower, flood control, drinking water, etc. Dam failure occurs due to different reasons (i.e. structural instability conditions, hydraulic conditions, overtopping, seepage or piping through the dam body or its foundation). Also, dams might suddenly collapse due to the occurrence of earthquakes, landslides or terrorist attacks. From the learnt lessons of these disasters, most countries started to make emergency plans to assess the risk analysis for each dam along their rivers. Egypt, also, started to be aware of the danger that might face the country in case of AHD collapse. The AHD is designed for century storage of the Nile River discharges. Its failure would cause a disaster to Egypt and would cause a big loss in life, land and property. This study thus started on track with the objective of predicting the hydraulic hazards of inundation in the Nile Valley due to the failure of the AHD. A large amount of available hydraulic data were analyzed and were used as input data to flood model (SOBEK 1D2D). GIS tools was used to produce a precise DEM to the Nile Valley, Egypt, and implemented in order to determine the banks violation sites together with the inundation of surrounding areas. So the size of expected damage of national main structures, (Railways, roads, airports, etc) within the extension of the study area was identified using GIS spatial database. The general objective of this research is to assess the impact of such a catastrophic event on the inhabited areas downstream the AHD, or any urban area which might be in the path of the flood surge waves.

\section{LITERATURE REVIEW}

Dam break of completely or partially failure studies can be carried out by scaled physical models which devilry light costly due to loge sage of dam's structures distorted, or scaled. Also, the difficulties of representing terrain feature of the inundated areas downstream the dam. But generally the using of physical models in hydraulic studies is a very representative tool used to predict the behavior of the studied case. Also, many sophisticated computer programs have been developed in the recent few years to simulate the flood inundation due to rural flood plain and dam partially breach or completely failure. Most of these models are based on solving and spreading unsteady flow solutions, mainly SaintVenant equation with different schemes of solutions. These models were recently adopted to be more accurate more representatively, more easily to be used, and flexible to deal and combine with other helping software like GIS, AutoCAD, etc.
CRISTOFANO, BREACH, HEC-RAS, BOSSDAMBRK, BIPLAN, SOBEK, DEICH N1/N2, MIKE11, and CCH2D-DAMREAK are some applicable dam-break models, [2, 3, 6, 7, 10 and 11]. The review of these existing breach models showed that, models should always use with caution and the users should understand the assumptions and limitations of each model. As these models might have been developed for specified cases without enough calibration and validation, or include unrealistic assumptions.

Over the past few years, GIS has gained considerable importance in engineering applications particularly in the fields of hydrology and hydraulics. It began at the 1980 s, and then its applications were developed to powerfully represent the flow of water on the different features of land surface terrain. De Vantier and Fledman, (1993) reviewed the connection between GIS and hydraulics modeling. This review summarized past efforts and current trends in using Digital Terrain Models and GIS to perform hydraulics and hydrological analysis. The link between GIS and these modeling becomes more popular as concern for spatially distributed terrains parameters and the use of computers for hydraulic analysis turns them more popular. GIS deals with terrain data of the studied areas in different ways of mapping, depending on the type of hydraulic model used and related to the capacity of computers used, [5 and 14].

Recently many of countries that have dams on their national rivers are prepared a safety plan against the risk analysis of different scenarios of these dams failure, (i.e. Trigis Rivers in Iraq, Falcon Dam on the Rio Grande River, Sistan River (Iran), Geldersche Valley (Netherlands) and in the Nile River in Egypt), $[6,9,12$ and 13]. Actually there is no previous hydraulic modeling of any intermediate barrages along the Nile path or on the main diverted canals within Egypt borders, except some economic studies about the possible damages of some main barrages likes Esna, Assiut Barrage, and some intermediate regulators likes Shoubra-Bas, Idefena and Ibrahimia regulators. From the reviewed literature, it was clear that several researchers dealt with dam breaching, worldwide, due to the importance of the dam in the Egyptian lives, this study was initiated in order to assess the breaching risks.

\section{Numerical Models}

In this research, SOBEK Rural-1D combined with SOBEK-2D (Overland flow) were used for simulating the Nile River as 1D and the Nile Valley area as $2 \mathrm{D}$. Furthermore, the outflow hydrograph due 
to AHD failed was considered form the output of Abdelhaleem, F. (2011), [1].

In this section, the SOBEK model description together with its basic equations and scheme of solution are presented, as follows:

\subsection{Model Description}

SOBEK name is mainly derived from the ancient Egyptian River God "Crocodile". Crocodiles were believed to have predictive powers as they would lay their eggs just above the level of the upcoming Nile flood. SOBEK has been developed by WL| Delft Hydraulics in partnership with the National Dutch Institute of Inland Water Management and Wastewater Treatment, and the major Dutch consulting companies, [4].

In the present study, SOBEK Rural-1D combined with SOBEK-2D (Overland flow) were used for simulating the Nile River as $1 \mathrm{D}$ and the Nile Valley area as 2D. SOBEK Rural-1D Flow is a onedimensional model that can simulates the flow and water quality in river and estuary systems. SOBEKOverland flow is a two-dimensional modeling system which supports the work of engineers related to flood studies. In a typical application, the program is used to simulate the progression of flood waters and the depth of flooding in an area along a river or a canal. The program calculates water depths and velocities in the flood area, which is represented by a twodimensional grid. The flow module is capable of simulating a fully unsteady flow in the Nile River. The overland module is capable of simulating the progression of flood waters and the depth in the Nile Valley.

\subsection{Basic Equations}

The program calculates water depths and velocities in the flood area, which is represented by a twodimensional grid. As for the river simulations, the most relevant model that was used is the flow module which is capable of simulating a fully unsteady flow in river channels. The governing equations used to describe the channel flow and overland flow, are illustrated in the following points:

Basic equations used for 1D computation

SOBEK-Channel flow is a one-dimensional modeling system that can simulate the flow and water quality in river and estuary. The governing equations used to describe the channel flow, are full Saint-Venant equations for unsteady open channel flow, which represent a regular river application, as follows:

- Continuity equation (representing the conservation of mass)

$\frac{\partial A_{t}}{\partial t}+\frac{\partial Q}{\partial x}=q_{\text {lat }}$

- Momentum equation (representing the conservation of momentum) $\frac{\partial Q}{\partial t}+\frac{\partial}{\partial x}\left(\alpha_{B} \frac{Q^{2}}{A_{f}}\right)+g A_{f} \frac{\partial h}{\partial x}+\frac{g Q|Q|}{C^{2} R A_{f}}=0$

where:

$\mathrm{A}_{\mathrm{f}} \quad$ : conveying cross-section

$\mathrm{A}_{\mathrm{t}} \quad$ : total cross-sectional area

C : Chézy coefficient

g : gravitational acceleration

$\mathrm{h} \quad$ : water level relative to reference level

$\mathrm{q}_{\text {lat }} \quad$ : lateral inflow per unit length

Q : discharge

$\mathrm{R}$ : hydraulic radius (roughly equal to the water depth)

$\mathrm{t} \quad$ : time

$\mathrm{W}_{\mathrm{f}} \quad$ : width of conveying cross-section at water surface

$\mathrm{x} \quad$ : distance along the channel

$\alpha_{B} \quad$ : Boussinesq coefficient

The Boussinesq coefficient is a correction factor in the convective acceleration term in equation (1), to account for non-uniform velocity distribution in the cross-section. It is computed as:

$\alpha_{B}=\frac{\sum_{i=1}^{n} C_{i}^{2} R_{i} A_{f i}}{C^{2} R A_{f}}$ and $: C^{2} R=\left(\frac{\sum_{i=1}^{n} C_{i} A_{f i} \sqrt{R_{i}}}{A_{f}}\right)^{2}$

in which; i: index indicating type of sub-section in conveying cross-section $(i \leq 3)$

The last expression in equation (3), computing a representative $C^{2} R$, is also used in the bed-friction term in equation (4). The Chézy coefficient $\mathrm{C}$ is in this model computed as a function of Manning's roughness coefficient $\mathrm{n}_{\mathrm{m}}$ :

$C=\frac{R^{1 / 6}}{n_{m}}$

For the Nile River model the Manning type roughness coefficient provides a good representation of hydraulic roughness for a wide range of discharges.

- Basic equations used for $2 D$ computation

The following basic equations are used for the 2D computation:

$$
\begin{aligned}
& \frac{\partial \zeta}{\partial t}+\frac{\partial(u h)}{\partial x}+\frac{\partial(v h)}{\partial y}=0 \\
& \frac{\partial u}{\partial t}+u \frac{\partial u}{\partial x}+v \frac{\partial u}{\partial y}+g \frac{\partial \zeta}{\partial x}+g \frac{u / V /}{C^{2} h}+a u \backslash u \backslash=0 \\
& \frac{\partial v}{\partial t}+u \frac{\partial v}{\partial x}+v \frac{\partial v}{\partial y}+g \frac{\partial \zeta}{\partial y}+g \frac{v / V /}{C^{2} h}+a v \backslash v \backslash=0 \\
& \text { 7) } \\
& \text { where: }
\end{aligned}
$$$$
\mathrm{u} \text { : velocity in } \mathrm{x} \text {-direction }
$$$$
\mathrm{v} \text { : velocity in y-direction }
$$ 


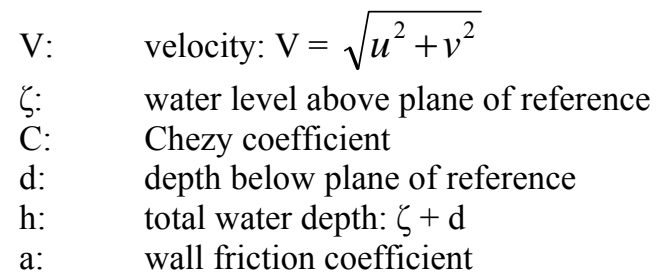

These equations describe unsteady two-dimensional shallow flow. The equation (5) the so-called continuity equation, ensures the conservation of fluid. The equations (6) and (7) are the momentum equations. They consist of acceleration terms, the horizontal pressure gradient terms, advective terms, bottom friction terms and wall friction terms. These equations are non-linear and they are a subset of the well-known shallow water equations that describe water motion with small vertical accelerations compared to the horizontal accelerations (this applies to tidal flow, river flow, and flood flow).

As opposed to the shallow water equations, equations (7) didn't incorporate the turbulent stress terms, accounting for the sub-grid transfer of momentum in between grid-cells. These terms were omitted as they are relatively unimportant for flood flow computations and also to save computational effort. The wall friction terms have been introduced to account for the added resistance that is caused by vertical obstacles, like houses or trees. The wall friction coefficient is based on the average number and diameter of the obstacles per unit area and the average obstacle drag coefficient $\left(\mathrm{C}_{\mathrm{d}}\right.$ coefficient).

\subsection{Model Assumptions}

Outflow hydrographs due to the failure of AHD were obtained From Abdelhaleem studied. The worst scenario was used as upstream boundary condition for the SOBEK model. SOBEK was operated and the results were analyzed The high water levels along the valley, flood arrival times, as well as stage and discharge hydrographs at specified locations can be obtained from the results of the SOBEK model.

Primarily, assumptions were put forward to initiate the computation. During analyzing the results, the following were considered.

- Bank failure does not occur due to excessive discharges.

- The debris, present in the barrages fore-bays that could obstruct the vents during the passage of the flood wave, is absent.

- All the gates of the main barrages, downstream the AHD, were opened when the flood wave reaches them. These gates are failed when the flood discharge reaches $7000 \mathrm{~m}^{3} / \mathrm{s}$.

- The bridges, along the Nile, are sabotaged when the water level reaches their deck

- Erosion does not take place during the simulations.

- The lateral off-takes, all side canals and Rayahs upstream the barrages worked with their maximum capacity during the flood.

\subsection{Model Schematization}

The Nile River is described through 4 reaches. Figure 1 shows the schematization of the Nile, with its nodes, branches and its main structures. The model schematization was concerned with the four reaches to simulate the $1 \mathrm{D}$ modeling of the river flow and concerned with $2 \mathrm{D}$ over flow land. Up-stream conditions were set as the hydrograph of the worst scenario that obtained by Abdelhaleem, [1].

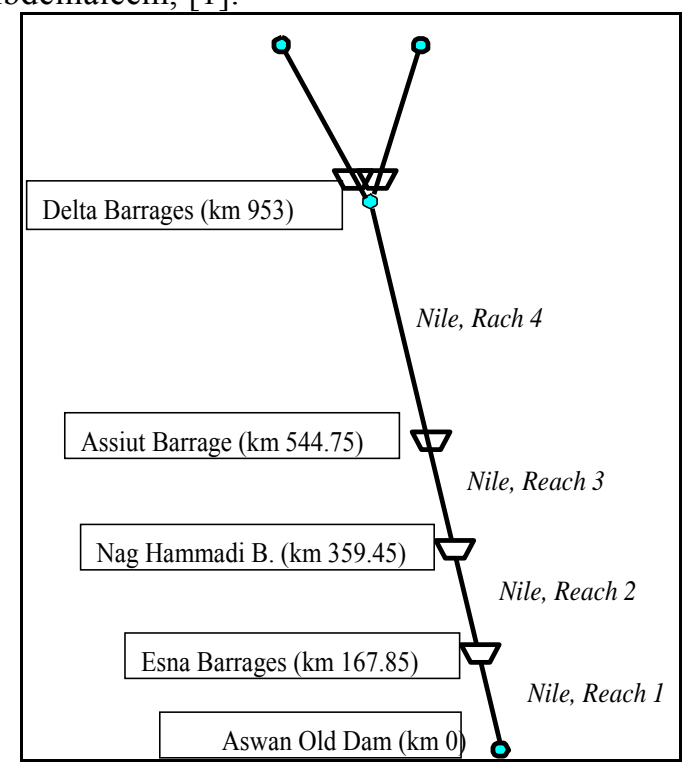

Figure 1: Schematization of the Nile River

Downstream boundary conditions were set as the maximum water level upstream Delta barrages. Lateral in/outflow were specified for both point discharges $\left(\mathrm{m}^{3} / \mathrm{s}\right)$ for the main canals and all pumps that directly withdraw off the river, all minor abstraction canals and all drains returning water to the river within the reach under consideration. Every reach was spilt into segments bounded by two calculation nodes $200 \mathrm{~m}$ apart. The calculations were executed to the segments, structures and the intermediate nodes to produce the water levels, depths, velocities, discharges and some hydraulic characteristics. The simulation period considered six months period for failure.

\subsection{SOBEK Calibration and Validation}

Calibrations of the model were done based on real measurements of inflows, discharges, and water levels. The measurements were carried out by the Hydraulics Research Institute at January 2010. To validate SOBEK model, the data of flood seasons 1998/1999 were used. The validations were done in two schemes as follows: 
- Validating water profiles along the different reaches.

- Comparing the results of the hydraulic flow characteristics at a number of hydrometric stations. Several model runs were made to achieve the best agreement between measured and computed values from the model. This was carried out by adjusting roughness coefficients at various locations along the modeled reaches. Table 1, presents the hydraulic roughness values along the Nile River reaches this in case of 1D model (the Nile River). For the Nile Valley, (2D model) the area of the flood plain is classified as building, urban, rural, etc. and the roughness are estimated based on the classification of the US Army Corps of Engineers, [13].

Table1. Hydraulic roughness values determined by model calibration

\begin{tabular}{|c|c|c|}
\hline Reach No. & $\begin{array}{c}\text { Reach } \\
\text { (1D Model) }\end{array}$ & $\begin{array}{l}\text { Determined Manning factor (n) } \\
\text { Roughness in SOBEK-River } \\
\left(\text { (s. } \text { m }^{-1 / 3}\right)\end{array}$ \\
\hline 1 & Aswan-Esna & 0.026 \\
\hline 2 & Esna -Naga Hammadi & 0.023 \\
\hline 3 & Naga Hammadi -Assuit & 0.022 \\
\hline 4 & Assuit-Delta Barrage & 0.030 \\
\hline \multirow[b]{2}{*}{ No. } & \multirow{2}{*}{$\begin{array}{l}\text { classification } \\
\text { (2D Model) }\end{array}$} & Estimated Manning factor (n) \\
\hline & & $\begin{array}{l}\text { Roughness in SOBEK-over flow } \\
\text { (s.m-1/3) }\end{array}$ \\
\hline 1 & Urban & 0.25 \\
\hline 2 & Rural & 0.20 \\
\hline 3 & Mountains & 0.31 \\
\hline
\end{tabular}

The worst Scenario was simulated using SOBEK 1D2D Model, This scenario was chosen to be simulated by 1D 2D model because it represents the worst case. This scenario used the hydrograph as an upstream boundary condition for SOBEK 1D2D. Figure 2 shows the used hydrograph and the simulated period.

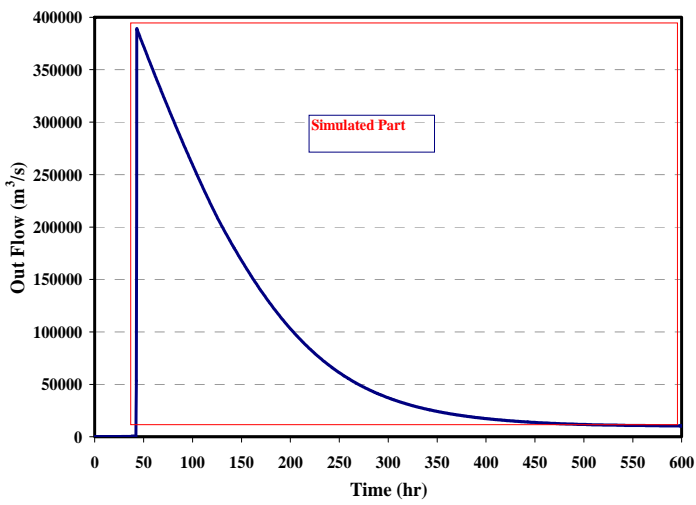

Figure 2: Upstream inflow hydrograph, after Abdelhaleem F. (2011), [1]

\section{GIS DEM Model}

\subsection{Model Description}

The SRTM $3^{\text {rd }}$ edition digital elevation data, produced by NASA originally, is a major breakthrough in digital mapping of the world, and provides a major advance in the accessibility of high quality elevation data for large portions of the tropics and other areas of the developing world

\subsection{Model Accuracy}

The NASA Shuttle Radar Topographic Mission (SRTM) has provided digital elevation data (DEMs) for over $80 \%$ of the globe. This data is currently distributed free of charge by USGS and is available for download from the National Map Seamless Data Distribution System, or the USGS ftp site. The SRTM data is available as 3 arc second (approx. 90m resolution) DEMs. A1 arc second data product was also produced, but is not available for all countries. The vertical error of the DEM's is reported to be less than $16 \mathrm{~m}$. The data currently being distributed by NASA/USGS (finished product) contains "no-data" holes where water or heavy shadow prevented the quantification of elevation. These are generally small holes, which nevertheless render the data less useful, especially in fields of hydrological modeling.

\subsection{Model Modifications}

The model accuracy was enhanced using real measurements data obtained from the site during the HRI survey missions of the Nile River. Those data are covering both bathymetric and Topographic measurements which inserted to the dem model data for enhancing its accuracy in both horizontal and vertical axis. Samples of the comparison between the model results before and after modification are shown in Figures 3 and 4.

The vertical error of the DEM's after modification was less than $1 \mathrm{~m}$ and the resolution reduced from 90 $\mathrm{m}$ to $3 \mathrm{~m}$.

\section{1D2D Flood Model Results}

The hypothetical failure of the AHD due to the worst Scenario caused huge damages along the Nile River. These results are presented in Table 2 . In general, water velocity ranged between 0.5 to 18.5 $\mathrm{m} / \mathrm{s}$ according to the natural bed slopes, and the Nile cross-section width. After the failure, the velocity increased dramatically during the first few days. This increase in velocities extended from the failure site up to $400 \mathrm{~km}$ downstream the AHD. The first propagation wave takes about $95 \mathrm{hrs}$ to travel a distance of $953 \mathrm{~km}$ downstream the AHD, while under the normal flow conditions, the time of water movement from AHD to the Delta Barrages takes 280 to 295 hrs, as shown in Figures 5

\section{GIS Outputs}

6.1 Banks Overtopping and Violation Sites

The model showed that overtopping occurred after failure. The flooding continued for 3 months until the water level profile gets down. The banks were 
overtopped at all sites downstream the AHD. Figure 6 , shows the maximum water profile along the Nile River

\subsection{Inundated Areas and Maps}

To evaluate the effects of AHD failure, inundated maps were prepared delineating the area which was inundated in the event of failure. Land-uses and significant development or improvements within the area of inundation was indicated. The maps identified clearly the area that should be evacuated. Copies of the maps should be distributed to local government officials for use in the development of an evacuation plan, as shown in Figure10. In order to assess the risk analysis, ArcGIS software, (ArcMAP9) was used to establish an informative management database to map the different features (Governorates, Urban sites, Populations, Airports, Roads, Railways, and Metro lines). The GIS database was described as layers, Figure 7.

The total gross flooded area resulted for this scenario was about $24,000 \mathrm{~km}^{2}$, all of it within the Nile Valley borders. Figure 8 shows the GIS maps of inundated areas, and the inundated depths.

\subsection{Means of transportations}

Emergency plan evacuates the affected areas (i.e. airports, railroad, and roads that subjected to inundation).

Airports: 8 airports were subjected to inundations for the The worst Scenario.

Roads: 30 roads were inundated for this scenario, Railways and Metro Lines: 15 railways were inundated for this scenario, also the two metro lines.

\section{CONCLUSIONS}

The results of outflow hydrograph and the water levels of Abdelahleem F. study during the dam failure were used in order to simulate the flood wave propagation and inundation area in the Nile Valley.

The worst Scenario was chosen to be simulated by 1D2D SOBEK model because it represents the worst case. In the case of the Aswan High Dam failure, major damages can be expected along the Nile Valley. The resulting flood wave propagated down the Nile valley causing the failure of all other dams by overtopping. The calculated flows were much larger than the discharge capacities of the main barrages. The wave travels down the Nile with a velocity that ranged between 0.5 and $18.5 \mathrm{~m} / \mathrm{s}$. The first propagation wave takes about $95 \mathrm{hrs}$ to travel a distance of $953 \mathrm{~km}$ downstream the AHD. The total gross flooded area resulted for this scenario was about $24000 \mathrm{~km}^{2}$. All of it was within the Nile Valley borders.

\section{NOTATION}

- 1D : One dimensional,

- AHD : Aswan High Dam,

- AOD : Aswan Old Dam,

- BCM : Billion Cubic Meters,

- d50 : Median grain size of sediment,

- DEM :Digital Elevation Model,

- DTM :Digital Terrain Model,

- GIS :Geographical Information systems,

- L.B. : Left Bank

- MCM : Million Cubic Meters, and

- m+MSL: meter above Mean Sea Level.

\section{ACKNOWLEDGMENTS}

This work was carried out at the Hydraulics Research Institute, National Water Research Center, Egypt. This study was done within the technical cooperation established between HRI and Civil Engineering Department, Faculty of Engineering, Minufiya University. The authors gratefully acknowledge the collaboration and effort done by all staff members of the Institute especially Dr. Fahmy Salah Abdelhaleem for providing with valuable data.

\section{REFERENCES}

[1]Abdelhaleem, Fahmy (20011), "Inundation Hazards and flood wave Propagation due to Dams failure", $\mathrm{PhD}$ thesis, Menoufiya University, Egypt

[2]Broich K. (1998),"Mathematical Modeling of Dam-Break Erosion Caused By Overtopping", Concerted Action on Dam-Break Modeling Proceedings, Munich

[3]Cristofano E. A. (1965),"Method of Computing Erosion Rate for Failure of Earth-fill Dams", US Bureau of Reclamation, Denver

[4]Delft Hydraulics (2004),"SOBEK manual Help", Technical Reference Manual. Delft Hydraulics, IHE, Delft, the Netherlands

[5]De Vantier and Fledman (1993),"Review of GIS applications in hydrologic modeling" Journal of Water Resources Planning and Management 119, P. 246-261

[6]Fread D. L. (1988), "BREACH: an Erosion Model for Earthen Dam Failures", Model description and User Manual, US National Weather Service

[7]HEC (1983b), HEC-RAS User Manual", Version 1.2.0, CPD-68, US Army Corps of Engineers, Hydrologic Engineering Center, Davis, California 
[8]Hurst, Blak, and Simaika (1966), "The Major Nile Projects", Ministry of Irrigation, the Nile Basin, Vol. $\mathrm{X}$

[9]Lomulder R. (2004), "Appropriate modeling: Application of SOBEK 1D2D for dike break and overtopping at the Elbe" $\mathrm{PhD}$. thesis, University of Twente

[10]M. A. A. Mohamed, Paul G. Samuels, Gurmel Ghataora, and Mark W. Morris, (2002). "A New Methodology to Model the Breaching of NonCohesive Homogeneous Embankments", HRWallingford, Howbery, Wallingford

[11]Macdonald $\mathrm{T}$ and Langridge $\mathrm{M}$. (1984),"Breaching Characteristics of Dam Failures" Journal of Hydraulic Engineering, Vol. 110, No. 5, P. $567-586$

[12]Sloff C.J., Ogink H. and Janssen A.P.A.M. (2004), "SOBEK-Nile schematization, calibration and verification". Technical Report, work package 1.6. WL| Delft Hydraulics, Report Q3181

[13]US Army Corps of Engineers (2008), "Dam Break Analysis for PuuLua Reservoir", Final Report, Honolulu, Hawaii

[14]Xu, Z. X., Ito, K., Schuiltz, G. A., and Li, Y. J., (2001),"Integrated Hydrologic Modeling and GIS in Water Resources Management" Journal of Computing in Civil Engineering, Vol. 15, NO. 3, July 2001. ASC. 
Amin, A. M. and Helal Y. Esam, "GIS Application on Risk Hazards Assessment ..."

Table 2: Hydraulics characteristics along the Nile River

\begin{tabular}{|c|c|c|c|c|c|c|c|}
\hline $\begin{array}{c}\text { Distance } \\
\text { from } \\
\text { AOD } \\
(\mathrm{Km})\end{array}$ & Description & $\begin{array}{c}\text { Initial } \\
\text { Water } \\
\text { Level } \\
\text { (m) }\end{array}$ & $\begin{array}{l}\text { Maximum } \\
\text { Water } \\
\text { Level } \\
\text { (m) }\end{array}$ & $\begin{array}{l}\text { Time of } \\
\text { wave } \\
\text { arrival } \\
\text { (hour) }\end{array}$ & $\begin{array}{l}\text { Maximum } \\
\text { Flow }\left(\mathrm{m}^{3} / \mathrm{s}\right)\end{array}$ & $\begin{array}{l}\text { Maximum } \\
\text { Velocity } \\
(\mathrm{m} / \mathrm{s})\end{array}$ & $\begin{array}{l}\text { Time of } \\
\text { Maximum } \\
\text { Water } \\
\text { Level } \\
\text { (hour) } \\
\end{array}$ \\
\hline 0.00 & $\begin{array}{l}\text { US Aswan Old } \\
\text { Dam }\end{array}$ & 110.80 & 166.18 & 0 & 387150.3 & 6.59 & 87 \\
\hline 0.10 & $\begin{array}{l}\text { DS Aswan Old } \\
\text { Dam }\end{array}$ & 85.70 & 165.12 & 0 & 387150.3 & 6.59 & 87 \\
\hline 7.00 & Aswan & 85.28 & 165.11 & 1 & 383192.5 & 6.99 & 93 \\
\hline 50.00 & Kom Ombo & 83.20 & 160.79 & 2 & 107330.80 & 4.46 & 121 \\
\hline 111.00 & Idfu & 79.80 & 158.53 & 3 & 77293.63 & 3.75 & 129 \\
\hline 167.85 & $\begin{array}{l}\text { US New Esna } \\
\text { Br. }\end{array}$ & 79.00 & 126.53 & 6 & 56967.85 & 4.78 & 375 \\
\hline 167.95 & $\begin{array}{l}\text { DS New Esna } \\
\text { Br. }\end{array}$ & 73.93 & 126.47 & 6 & 56967.85 & 4.78 & 375 \\
\hline 223.00 & Luxor & 71.62 & 117.02 & 9 & 21251.76 & 1.59 & 498 \\
\hline 285.50 & Qena & 68.70 & 106.41 & 11 & 20236.26 & 4.82 & 604 \\
\hline 363.00 & $\begin{array}{l}\text { US Naga } \\
\text { Hammadi Br. }\end{array}$ & 65.40 & 90.36 & 14 & 18559.90 & 3.54 & 866 \\
\hline 363.10 & $\begin{array}{l}\text { DS Naga } \\
\text { Hammadi Br. }\end{array}$ & 61.26 & 90.32 & 14 & 18559.90 & 3.54 & 866 \\
\hline 405.00 & Girga & 58.76 & 87.17 & 22 & 16959.91 & 1.92 & 934 \\
\hline 443.00 & Sohag & 55.74 & 81.26 & 28 & 15869.86 & 2.51 & 1090 \\
\hline 544.75 & US Assuit Br. & 49.50 & 69.81 & 32 & 15453.86 & 2.28 & 1363 \\
\hline 544.85 & DS Assuit Br. & 47.74 & 69.80 & 32 & 15453.86 & 2.28 & 1363 \\
\hline 684.00 & El Menia & 35.91 & 48.31 & 63 & 14897.62 & 1.45 & 2015 \\
\hline 805.00 & Beni Suef & 26.00 & 41.23 & 71 & 13260.86 & 1.10 & 2241 \\
\hline 907.00 & Helwan & 18.65 & 31.59 & 82 & 13252.96 & 1.88 & 2338 \\
\hline 930.00 & Cairo & 17.60 & 26.15 & 91 & 13136.66 & 2.21 & 2343 \\
\hline 953.50 & US Delta Br. & 16.28 & 24.16 & 95 & 12988.95 & 2.07 & 2351 \\
\hline
\end{tabular}




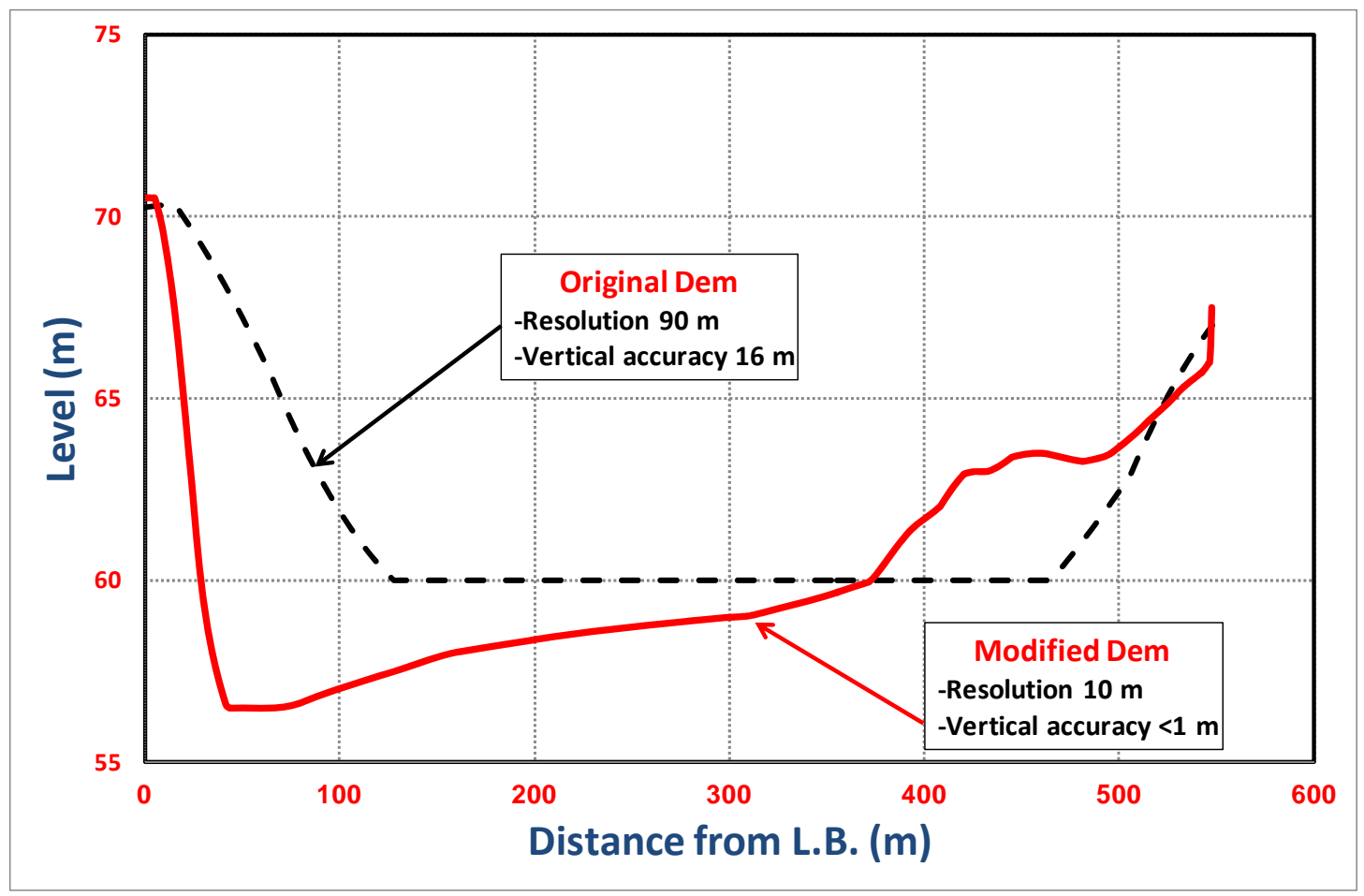

Figure 3: Sample of the Comparison between Original and Modified Dem (Reach 2)

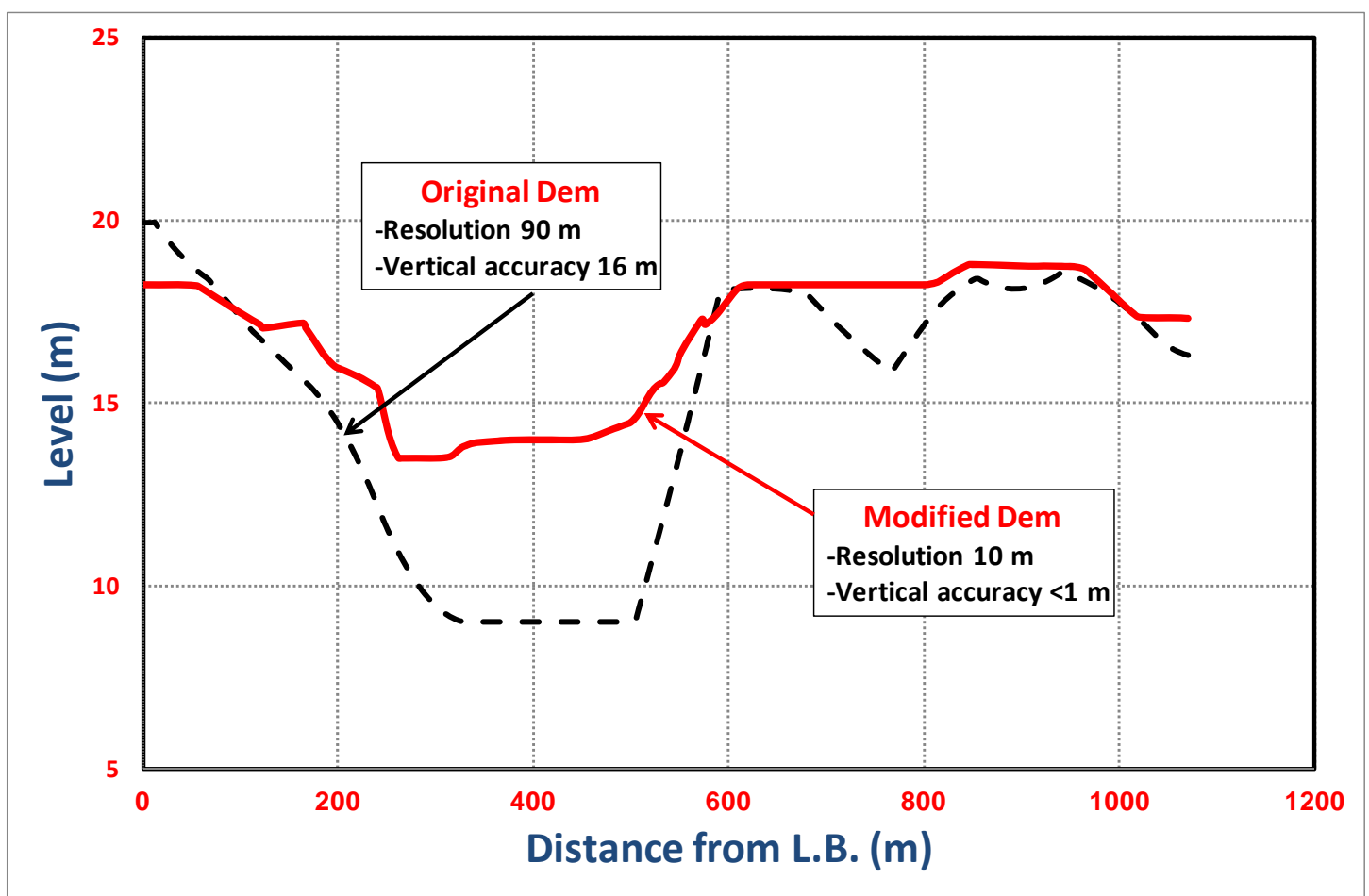

Figure 4: Sample of the Comparison between Original and Modified Dem (Reach 4) 
Amin, A. M. and Helal Y. Esam, "GIS Application on Risk Hazards Assessment ..."

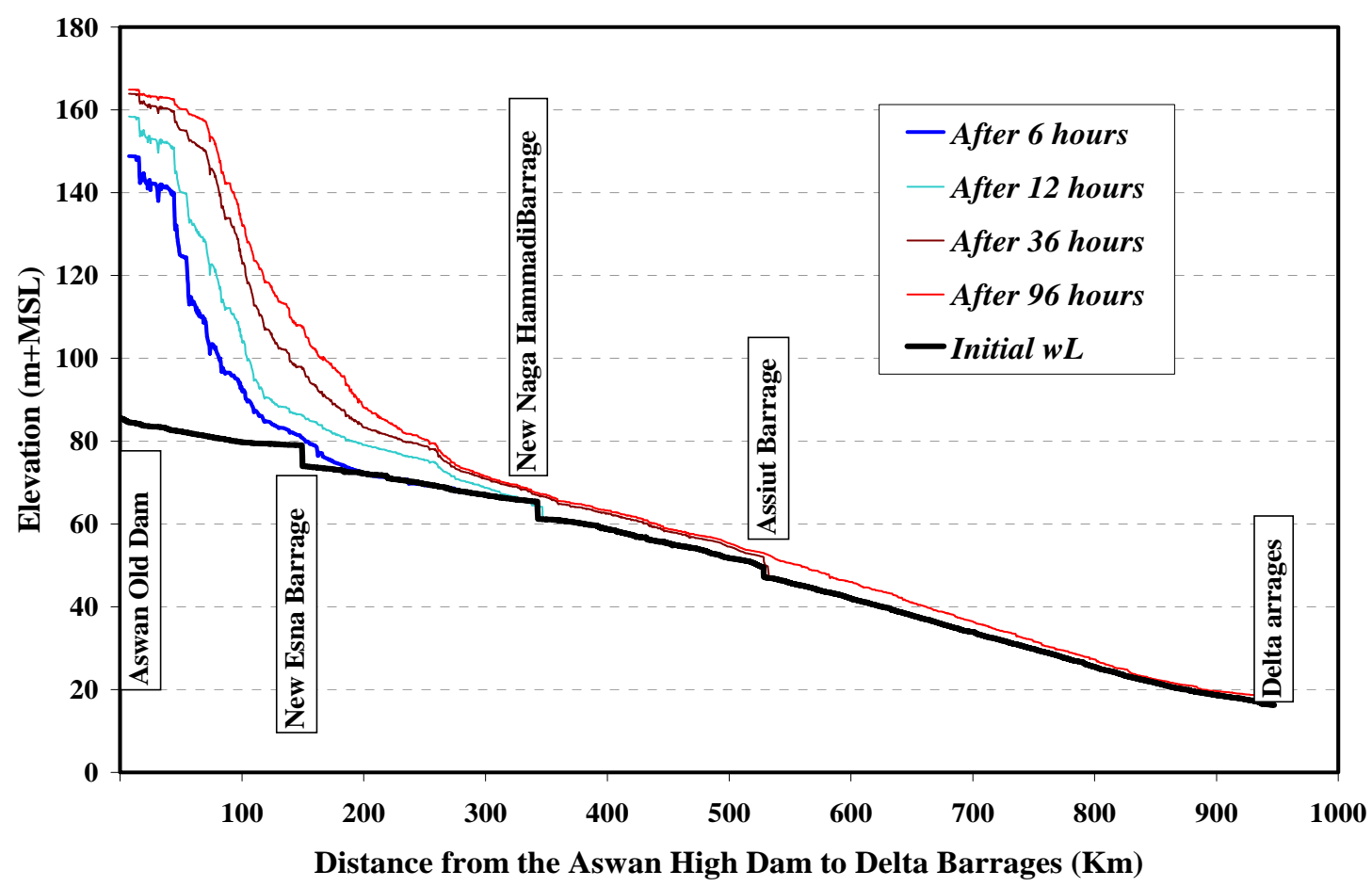

Figure 5: Longitudinal profile of flood wave propagation

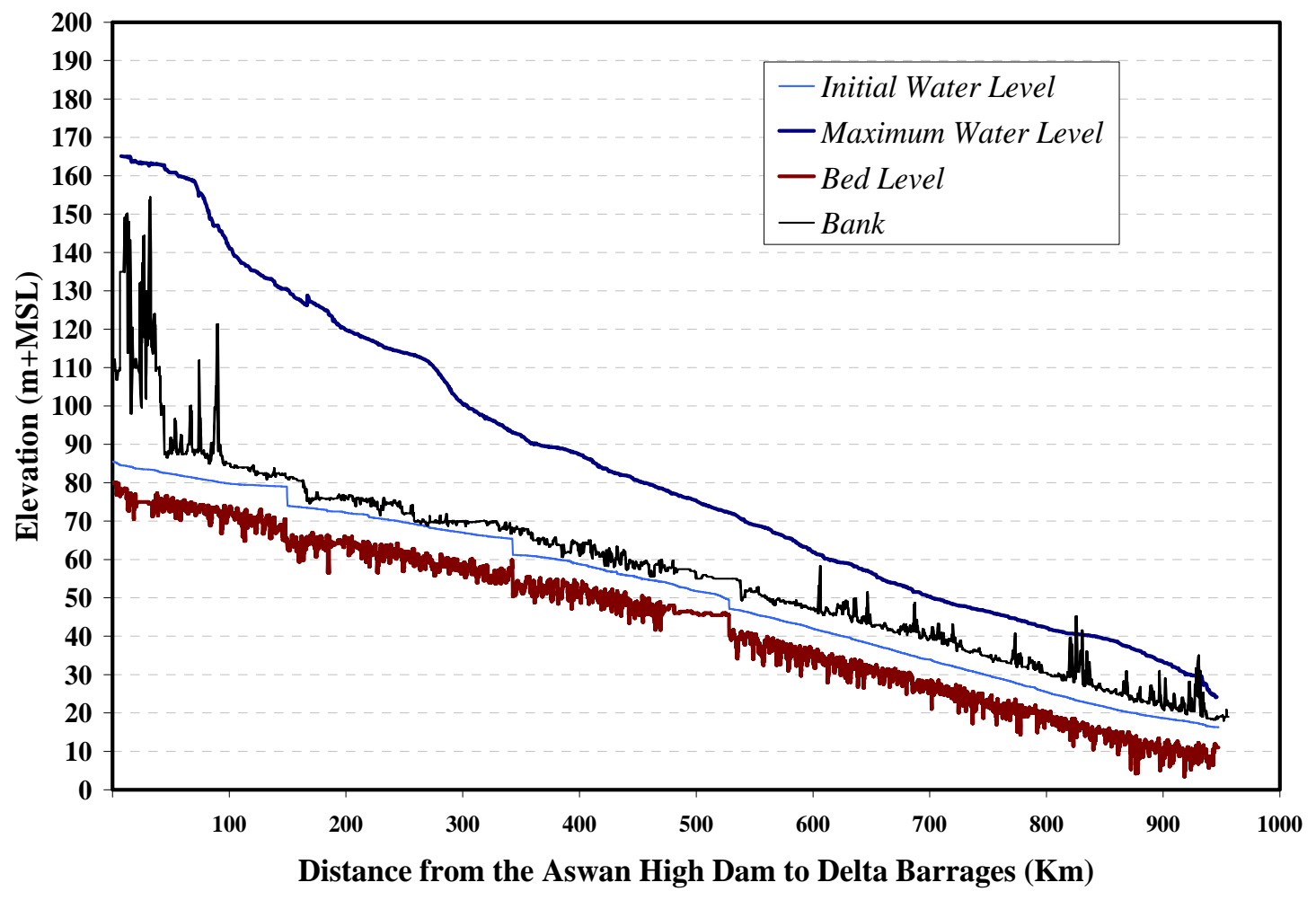

Figure 6: Peak water profile on the Nile River 


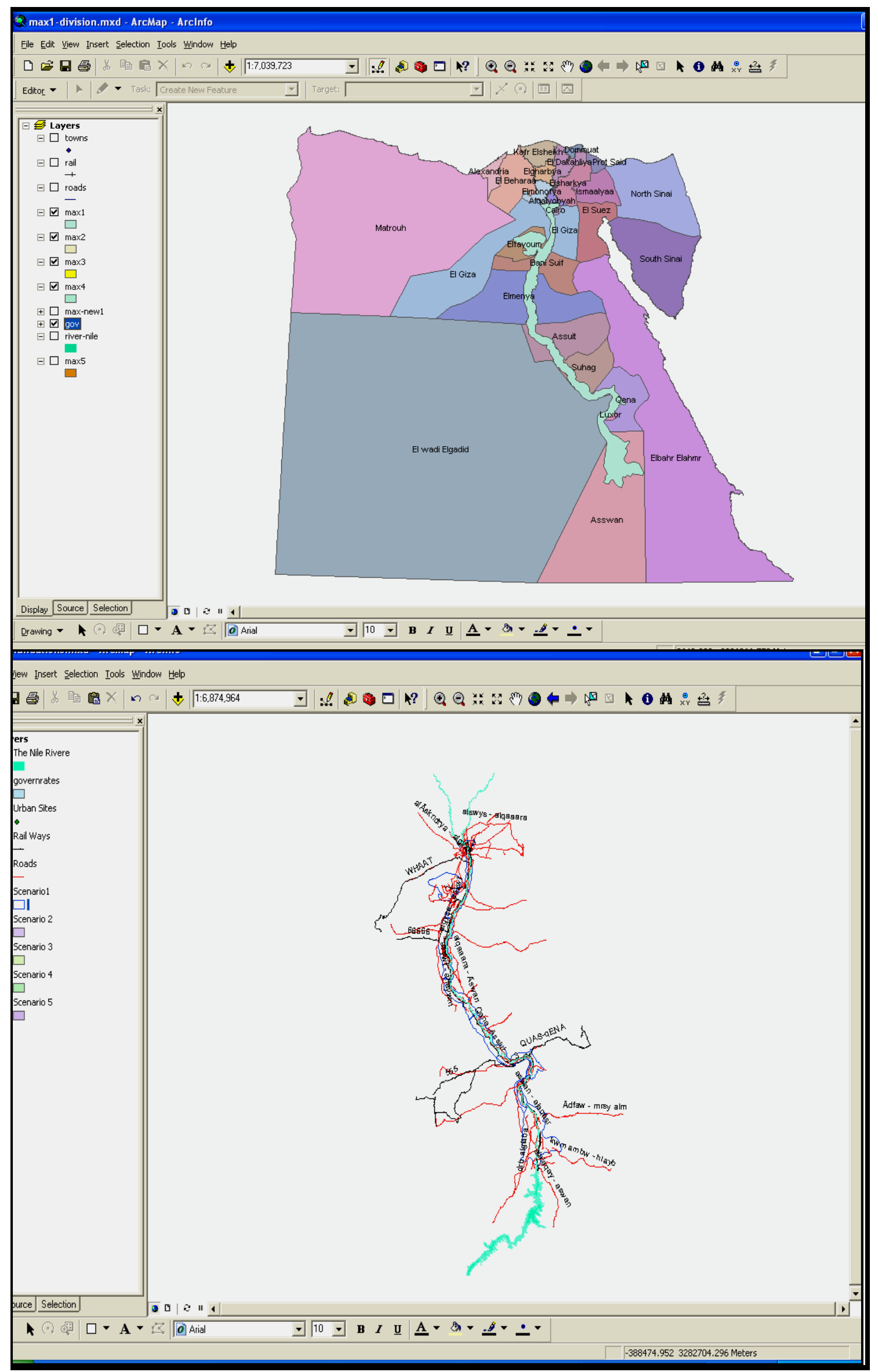

Figure 7: GIS database 

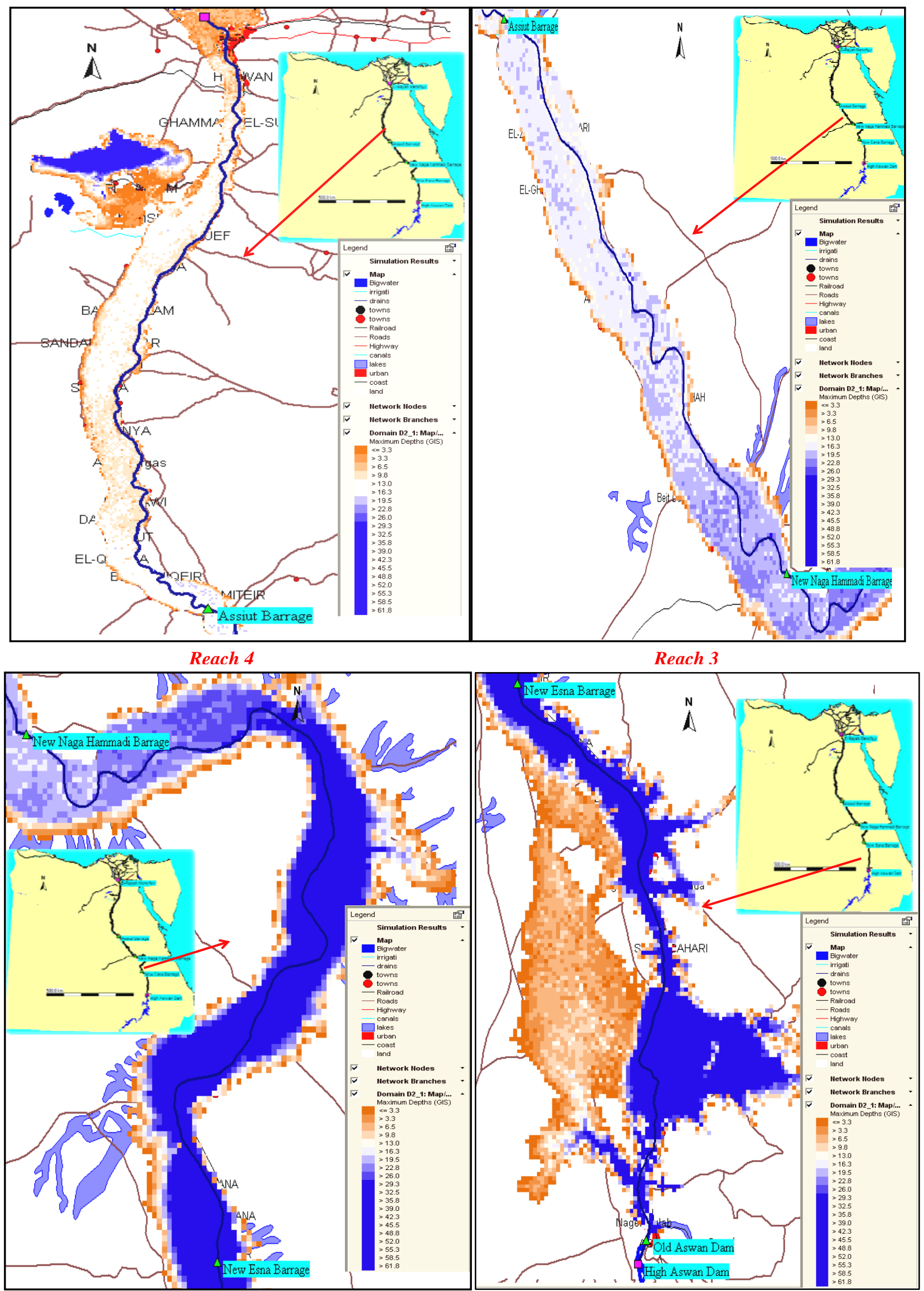

Reach 2

Reach 1

Figure 8: GIS Raster maps of inundation of the Nile Valley 